\title{
Isolation and Characterization of Paracoccus sp. GSM2 Capable of Degrading Textile Azo Dye Reactive Violet 5
}

\author{
Mallikarjun C. Bheemaraddi, Santosh Patil, \\ Channappa T. Shivannavar, and Subhashchandra M. Gaddad \\ Department of Post Graduate Studies and Research in Microbiology, Gulbarga University, Gulbarga, Karnataka 585106, India \\ Correspondence should be addressed to Channappa T. Shivannavar; ctshiv@gmail.com
}

Received 23 December 2013; Accepted 9 February 2014; Published 23 April 2014

Academic Editors: L. Beneduce, J. B. Gurtler, and J. Yoon

Copyright (C) 2014 Mallikarjun C. Bheemaraddi et al. This is an open access article distributed under the Creative Commons Attribution License, which permits unrestricted use, distribution, and reproduction in any medium, provided the original work is properly cited.

\begin{abstract}
A potential bacterial strain GSM2, capable of degrading an azo dye Reactive Violet 5 as a sole source of carbon, was isolated from textile mill effluent from Solapur, India. The $16 \mathrm{~S}$ rDNA sequence and phenotypic characteristics indicated an isolated organism as Paracoccus sp. GSM2. This strain exhibited complete decolorization of Reactive Violet $5(100 \mathrm{mg} / \mathrm{L})$ within $16 \mathrm{~h}$, while maximally it could decolorize $800 \mathrm{mg} / \mathrm{L}$ of dye within $38 \mathrm{~h}$ with $73 \%$ decolorization under static condition. For color removal, the most suitable $\mathrm{pH}$ and temperature were $\mathrm{pH} 6.0-9.0$ and $25-40^{\circ} \mathrm{C}$, respectively. The isolate was able to decolorize more than $70 \%$ of five structurally different azo dyes within $38 \mathrm{~h}$. The isolate is salt tolerant as it can bring out more than $90 \%$ decolorization up to a salt concentration of $2 \%(\mathrm{w} / \mathrm{v})$. UV-Visible absorption spectra before and after decolorization suggested that decolorization was due to biodegradation and was further confirmed by FT-IR spectroscopy. Overall results indicate the effectiveness of the strain GSM2 explored for the treatment of textile industry effluents containing various azo dyes. To our knowledge, this could be the first report on biodegradation of Reactive Violet 5 by Paracoccus sp. GSM2.
\end{abstract}

\section{Introduction}

In 1856, the world's first commercially successful synthetic dye, mauveine, was discovered for practical uses. Over 10,000 different dyes with an annual production of over $7 \times 10^{5}$ metric tons worldwide are commercially available $[1,2]$. Azo dyes are the diverse group of synthetic organic compounds accounting for the majority of all textile dyestuffs produced and are the most extensively used in a number of industries such as textile dyeing, paper, food, leather, cosmetics, and pharmaceutical industries [3]. The amount of dye lost depends upon the class of dye application, varying from $2 \%$ loss while using basic dyes to $50 \%$ loss in certain reactive sulfonated dyes, leading to severe contamination of surface and ground waters in the vicinity of dyeing industries [4]. In India, an average mill discharges about 1.5 million liters of contaminated effluent per day, which leads to chronic and acute toxicity [5]. Improper textile dye effluent disposal in aqueous ecosystems leads to the reduction in sunlight penetration which in turn decreases photosynthetic activity, dissolved oxygen concentration, and water quality and depicts acute toxic effects on aquatic flora and fauna, causing severe environmental problems worldwide [6]. They can also cause human health disorders such as nausea, hemorrhage, ulceration of the skin and mucous membranes, and severe damage to kidneys, the reproductive system, liver, brain, and central nervous system [7]. In addition, azo dyes also have an adverse impact in terms of total organic carbon (TOC), biological oxygen demand (BOD), and chemical oxygen demand (COD) [8]. Many synthetic azo dyes and their metabolites are toxic, carcinogenic, and mutagenic [9]. Therefore, the treatment of industrial effluents containing azo dyes and their metabolites is necessary prior to their final discharge to the environment.

Various physicochemical methods like adsorption, chemical precipitation and flocculation, photolysis, chemical oxidation and reduction, electrochemical treatment, and ion pair extraction have been used for the removal of dyes from 
wastewater [10]. The major drawbacks of these methods have been largely due to the high cost, low efficiency, limited versatility, interference by other wastewater constituents, and the handling of the waste generated [11]. Conversely, biological processes provide an alternative to existing technologies because they are more cost-effective, environmental friendly and do not produce large quantities of sludge. Many microorganisms belonging to the different taxonomic groups of bacteria, fungi, actinomycetes, and algae have been reported for their ability to decolorize azo dyes [12]. Pure fungal cultures have been used to develop bioprocesses for the mineralization of azo dyes, but the long growth cycle and moderate decolorization rate limit the performance of fungal decolorization system [13]. In contrast, bacterial decolorization is normally faster. Bacteria capable of dye decolorization/biodegradation either in pure cultures or in consortia have been reported [11, 14-17]. However, comprehensive solutions for sulfonated azo dyes removal are far from reality, which calls for continued search for new organisms and technologies.

This study aimed to isolate and characterize an efficient bacterial strain, which exhibited the remarkable ability to degrade Reactive Violet 5 as a sole source of carbon. Various physicochemical parameters have been optimized for efficient dye decolorization. The dye degraded products were characterized by ultraviolet-visible (UV-Vis) and Fourier transformed infrared spectroscopy (FT-IR) techniques. Very few reports are available on Reactive Violet 5 degradation. After survey of the literature, this could be the first report on biodegradation of Reactive Violet 5 by Paracoccus sp. GSM2.

\section{Materials and Methods}

2.1. Dyes and Chemicals. Six textile azo dyes Reactive Violet 5, Reactive Red 2, Reactive Orange 16, Reactive Blue 4, Reactive Black 5, and Reactive Green 19 A were generous gifts from Colors India Inc. Pvt. Ltd., Ahmedabad, India. All these dyes were of industrial grade and are widely used in textile industries. Reactive Violet 5 was used as a model azo dye in this study (Figure 1). All required chemicals were obtained from S.D. Fine chemicals (India) and Sigma-Aldrich, (USA). Biochemical and physiological test kits were obtained from Hi-Media, India. All chemicals used during the study were of analytical grade.

2.2. Culture Medium. The mineral salts medium (MSM) was prepared as per Brilon et al. [18] with some modifications. The MSM consisted of the following constituents (g/L): $\mathrm{Na}_{2} \mathrm{HPO}_{4} \cdot 2 \mathrm{H}_{2} \mathrm{O}$ (12.0), $\mathrm{KH}_{2} \mathrm{PO}_{4}$ (2.0), $\mathrm{NH}_{4} \mathrm{NO}_{3}$ (0.50), $\mathrm{MgCl}_{2} \cdot 6 \mathrm{H}_{2} \mathrm{O}(0.10), \mathrm{Ca}\left(\mathrm{NO}_{3}\right)_{2} \cdot 4 \mathrm{H}_{2} \mathrm{O}(0.050)$, and $\mathrm{FeCl}_{2} \cdot 4 \mathrm{H}_{2} \mathrm{O}(0.0075)$ with $10 \mathrm{~mL}$ of trace element solution per liter. The trace element solution was prepared as follows (mg/L): $\mathrm{ZnSO}_{4} \cdot 7 \mathrm{H}_{2} \mathrm{O}(10.0), \mathrm{MnCl}_{2} \cdot 4 \mathrm{H}_{2} \mathrm{O}$ (3.0), $\mathrm{CoCl}_{2} \cdot 6 \mathrm{H}_{2} \mathrm{O}(1.0), \mathrm{NiCl}_{2} \cdot 6 \mathrm{H}_{2} \mathrm{O}(2.0), \mathrm{Na}_{2} \mathrm{MoO}_{4} \cdot 2 \mathrm{H}_{2} \mathrm{O}$ (3.0), $\mathrm{H}_{3} \mathrm{BO}_{3}$ (30.0), and $\mathrm{CuCl}_{2} \cdot 2 \mathrm{H}_{2} \mathrm{O}$ (1.0). Further, MSM was blended with different concentrations of Reactive Violet 5 and used throughout the study as a test medium and uninoculated flasks were also incubated as control. The final $\mathrm{pH}$ of the medium was adjusted to $7.0 \pm 0.2$. The MSM with agar $(1.9 \%$ $\mathrm{w} / \mathrm{v}$ ) was used for isolation and maintenance of pure culture. The media were sterilized at $121^{\circ} \mathrm{C}$ for $20 \mathrm{~min}$ before use.

2.3. Screening, Isolation, and Identification of Dye Decolorizing Bacteria. Textile mill effluent collected from Solapur, India, was brought to the laboratory for isolation of dye degrading bacteria. $10 \mathrm{~mL}$ of sample was added to $100 \mathrm{~mL}$ of MSM broth containing Reactive Violet $5(100 \mathrm{mg} / \mathrm{L})$ as a sole source of carbon and incubated at $30^{\circ} \mathrm{C}$ for 15 days under static as well as shaking conditions. The flasks were checked for change in initial color and turbidity. Then $10 \mathrm{~mL}$ of culture broth from the decolorized culture flask was transferred to $100 \mathrm{~mL}$ of fresh MSM broth containing Reactive Violet 5 and incubated for one week under static condition. $0.5 \mathrm{~mL}$ of decolorized culture was taken out and spread over the agar plates of MSM containing dye and incubated at $30^{\circ} \mathrm{C}$ until prominent dye degrading bacterial colonies appeared. Further the prominent colonies were streaked onto the MSM agar plates amended with dye and $0.1 \%(\mathrm{w} / \mathrm{v})$ yeast extract. The obtained colonies formed were screened out and further were checked for the purity by streaking twice on agar medium. Finally, purified cultures were individually tested for their dye degrading capabilities in MSM under static condition. The potential isolate was preserved at $-20^{\circ} \mathrm{C}$ in $15 \%(\mathrm{w} / \mathrm{v})$ glycerol and used for further investigation. The potential isolate was selected and preliminarily characterized based on its morphological and biochemical properties [19]. Furthermore, various sugar utilization tests were performed using HiCarbo kit (Hi-Media, India).

2.3.1. $16 S$ rDNA Sequencing and Analysis. The 16S rDNA fragment was amplified and from the pure genomic DNA of isolated bacterial strain was sequenced at Royal Life Sciences Pvt. Ltd., Hyderabad, India. The genomic DNA was extracted using QIAGEN bacteria DNA purification kit according to manufacturer's instructions. The universal primers, namely, a forward primer, Eub27F $\left(5^{\prime}-3^{\prime}\right.$ : AGA GTT TGA TCC TGG CTC AG), and a reverse primer, Eub1492R ( $5^{\prime}-3^{\prime}:$ ACG GCT ACC TTG TTA CGA CTT), were used to amplify bacterial 16S rDNAs by PCR which yielded a product of approximately $1500 \mathrm{bp}$. After an initial denaturation at $95^{\circ} \mathrm{C}$ for $10 \mathrm{~min}$, the DNA was amplified during 25 cycles of $95^{\circ} \mathrm{C}$ for $1 \mathrm{~min}$, $55^{\circ} \mathrm{C}$ for $1 \mathrm{~min}$, and $72^{\circ} \mathrm{C}$ for $1.5 \mathrm{~min}$ and the final extension $\left(72^{\circ} \mathrm{C}\right)$ time was $10 \mathrm{~min}$. Then the purified PCR products were run on ABI-PRISM automated sequencer (ABI-3730 DNA Analyzer). A resultant of 1311 bases was compared with nine closely related taxa of the isolate, retrieved from the GenBank database using BLAST (blastn) program on the NCBI website (http://www.ncbi.nlm.nih.gov). The alignment of the sequences was done using CLUSTALW program V 1.6 at European bioinformatics site (http://www.ebi.ac.uk/Tools/msa/). The sequence was refined manually after crosschecking with the raw data to remove ambiguities and submitted to GenBank. To see the phylogenetic position of bacterial isolate evolutionary history was inferred using the neighbor-joining method [20]. The optimal tree with the sum of branch length = 
<smiles></smiles>

Figure 1: Structure of Reactive Violet 5.

0.28801765 is shown. The percentage of replicate trees in which the associated taxa clustered together in the bootstrap test (1000 replicates) is shown next to the branches [21]. The phylogenetic tree was linearized assuming equal evolutionary rates in all lineages [22]. The clock calibration to convert distance to time was 0.02 (time/node height). The tree is drawn to scale, with branch lengths in the same units as those of the evolutionary distances used to infer the phylogenetic tree. The evolutionary distances were computed using the maximum composite likelihood method [23] and are in the units of the number of base substitutions per site. Codon positions included were $1 s t+2 \mathrm{nd}+3 \mathrm{rd}+$ Noncoding. All positions containing gaps and missing data were eliminated. Evolutionary analyses were conducted in MEGA5 software [24].

2.4. Decolorization Experiment. The dye decolorization experiments were performed in $250 \mathrm{~mL}$ Erlenmeyer flasks containing $100 \mathrm{~mL}$ of sterilized MSM broth supplemented with yeast extract $(0.1 \% \mathrm{w} / \mathrm{v})$ and Reactive Violet 5 $(100 \mathrm{mg} / \mathrm{L})$. We recorded complete decolorization of Reactive Violet 5 in MSM with yeast extract within $16 \mathrm{~h}$ as compared to $56 \mathrm{~h}$ without yeast extract under the static condition (data not shown). Reports suggest that the inclusion of yeast extract was found to be most effective supplement for growth of azo dye degrading bacteria as well as increasing the dye decolorization efficiency $[13,25]$. Therefore all further decolorization experiments were performed using MSM broth supplemented with $0.1 \%(\mathrm{w} / \mathrm{v})$ yeast extract as a cosubstrate. The flasks were inoculated with $5 \mathrm{~mL}$ of cultures broth in test and uninoculated controls were used to compare abiotic color loss during the decolorization studies. The flasks were incubated at $30^{\circ} \mathrm{C}$ under static as well as shaking (120 rpm) conditions till the decolorization was completed. The $5 \mathrm{~mL}$ of cultures was withdrawn at different intervals for color measurement. The supernatant was collected by centrifuging at $10,000 \mathrm{rpm}$ for $15 \mathrm{~min}$. Decolorization was monitored spectrophotometrically by measuring absorbance of culture supernatant at $558 \mathrm{~nm}$. Growth of bacteria in dye containing medium was determined spectrophotometrically. The cell pellet obtained upon centrifugation of $5 \mathrm{~mL}$ culture was resuspended in $5 \mathrm{~mL}$ distilled water and its absorbance was studied at $660 \mathrm{~nm}$. The percentage of decolorization was calculated as mentioned by R. Dave and H. Dave [26]:

$$
\text { Decolorization }(\%)=\frac{I-F}{I} \times 100 \text {, }
$$

where $I=$ initial absorbance and $F=$ absorbance of decolorized sample.

2.5. Optimization of Physicochemical Parameters. The decolorization efficiency of Paracoccus sp. GSM2 on Reactive Violet 5 was studied at different $\mathrm{pH}(4-10)$ and temperatures values $\left(20-50^{\circ} \mathrm{C}\right)$. The obtained optimum $\mathrm{pH} 7.0$ and temperature at $30^{\circ} \mathrm{C}$ were selected to study the decolorization activity under various physicochemical factors such as initial dye concentration (100-800 mg/L), salt concentration (1-6\%), and yeast extract concentration $(0.1-2.0 \mathrm{~g} / \mathrm{L})$. Further, the decolorization of various azo dyes was studied by incubating MSM containing respective dye with bacterial strain GSM2 under static condition.

2.6. Decolorization and Biodegradation Studies. The Reactive Violet 5 degraded products formed during biodegradation after $16 \mathrm{~h}$ of incubation under static condition were studied by following the change in the UV-Vis spectra (200 to $800 \mathrm{~nm}$ ) using a UV-Vis spectrophotometer (Systronics, AU-2700). To know that the decolorization was due to biodegradation of Reactive Violet 5 was confirmed by FT-IR by analyzing dye degraded products in the decolorized medium. After complete decolorization, culture medium was centrifuged at $10,000 \mathrm{rpm}$ for $15 \mathrm{~min}$ to remove the suspended particles. The supernatant was once again centrifuged to ensure the supernatant was free of bacterial cells and was used for extraction of metabolites using an equal volume of ethyl acetate. The extracts were dried over anhydrous $\mathrm{Na}_{2} \mathrm{SO}_{4}$ and 


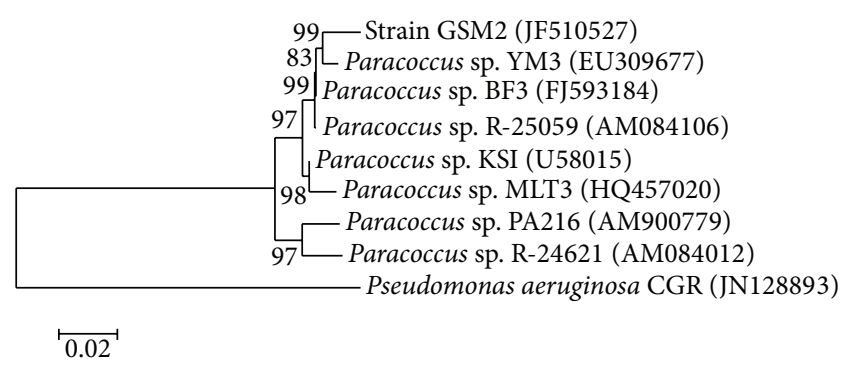

Figure 2: Phylogenetic tree of Paracoccus sp. GSM2 based on $16 S$ rDNA analysis.

concentrated in a rotary evaporator. The crystals obtained were dissolved in a small volume of high performance liquid chromatography (HPLC) grade methanol and the same sample was used for FT-IR analysis. The FT-IR analysis of extracted metabolites was done using Fischer Scientific (Nicolet, iH5) Spectrophotometer and compared with control dye in the IR region of $550-4000 \mathrm{~cm}^{-1}$ with 32 scan speed.

\section{Results and Discussion}

3.1. Isolation, Screening, and Identification. A total of seven morphologically distinct colonies were observed on the MSM agar plates (data not shown). Amongst positive strains subjected to screening, the potential bacterial strain GSM2 showed a rapid and complete decolorization of Reactive Violet 5 within $16 \mathrm{~h}$ under static condition and was selected for further study. The selected strain was gram negative, nonspore former, and nonmotile coccoid. Its colony was white to light yellow, round hunch, and slick. The potential strain was identified as Paracoccus sp. GSM2 on the basis of $16 \mathrm{~S}$ rDNA gene sequence and biochemical characteristics (Table 1). The $16 \mathrm{~S}$ rDNA sequence (1311 base pairs) was deposited in GenBank with accession number JF510527. Its $16 \mathrm{~S}$ rDNA sequence did not show any similarity to known azo dye degrader and had the greatest similarity to members of Paracoccus sp. group. The phylogenetic relationship between the Paracoccus sp. GSM2 and other related microorganisms using MEGA5 software can be depicted from Figure 2. Pseudomonas aeruginosa CGR has been taken as out-group and the numbers shown in parentheses are accession numbers of different species.

The homology assay result indicated that the Paracoccus sp. GSM2 in phylogenetic branch showed maximum similarity (99\%) to Paracoccus sp. YM3 which is already known for degradation of carbofuran [27]. Few reports are published on degradation of polycyclic aromatic hydrocarbons by Paracoccus sp. $[28,29]$. To our knowledge, this could be the first report on biodegradation of textile azo dye Reactive Violet 5 by Paracoccus sp. GSM2.

3.2. Effect of Static and Shaking Conditions. Paracoccus sp. GSM2 showed that $100 \%$ decolorization of added Reactive Violet $5(100 \mathrm{mg} / \mathrm{L})$ within $16 \mathrm{~h}$ under static condition when compared to only $16 \%$ decolorization was observed under shaking condition, while the growth of bacterium was greater
TABLE 1: Biochemical and sugar utilization tests of bacterial strain GSM2.

\begin{tabular}{|c|c|}
\hline Characteristics & Bacterial strain GSM2 \\
\hline Catalase & - \\
\hline Oxidase & + \\
\hline Urease & + \\
\hline Citrate utilization & - \\
\hline Nitrate reduction & + \\
\hline Glucose & + \\
\hline Adonitol & + \\
\hline Lactose & - \\
\hline Sorbitol & + \\
\hline Esculin hydrolysis & - \\
\hline Xylose & - \\
\hline Maltose & + \\
\hline Fructose & + \\
\hline Galactose & - \\
\hline Raffinose & - \\
\hline Trehalose & + \\
\hline Melibiose & - \\
\hline Sucrose & + \\
\hline L-Arabinose & + \\
\hline Mannose & + \\
\hline Inulin & + \\
\hline Sodium gluconate & + \\
\hline Glycerol & + \\
\hline Salicin & + \\
\hline Dulcitol & + \\
\hline Inositol & + \\
\hline Mannitol & {$[+]$} \\
\hline Arabitol & + \\
\hline Erythritol & {$[+]$} \\
\hline$\alpha$-Methyl-D-glucoside & + \\
\hline Rhamnose & + \\
\hline Cellobiose & + \\
\hline Melezitose & + \\
\hline$\alpha$-Methyl-D-mannoside & - \\
\hline Xylitol & - \\
\hline ONPG & - \\
\hline D-Arabinose & + \\
\hline Malonate utilization & + \\
\hline Sorbose & - \\
\hline
\end{tabular}

+: positive, [+]: weakly positive, and -: negative.

under shaking condition as compared to static condition (Figure 3). To confirm whether this decolorization was due to microbial action or due to change in $\mathrm{pH}$, the change in $\mathrm{pH}$ was recorded, which was in the range of 6.0-7.5 at static condition, thus confirming that the biodegradation of dye was due to microbial action. Under aerobic conditions azo dyes are generally resistant to attack by bacteria [30]. Similar findings were reported by other researchers $[14,15]$. During dye decolorization in shaking environment electrons released 


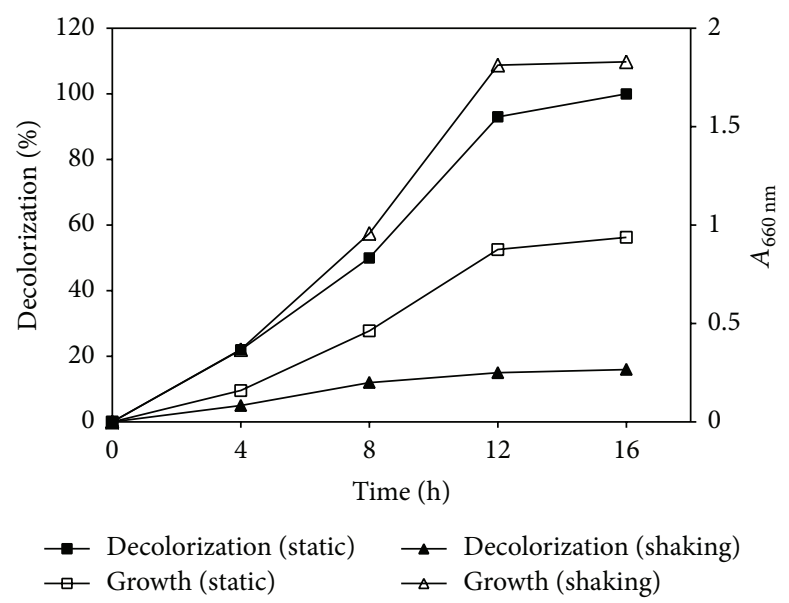

Figure 3: Decolorization of Reactive Violet 5 by Paracoccus sp. GSM2 in MSM under static and shaking condition (120 rpm) at $30^{\circ} \mathrm{C}$.

by oxidation of electron donors are preferentially utilized to reduce free oxygen rather than azo dyes [31]. Hence, in this study static conditions were maintained in the following experiments.

3.3. Effect of $p H$. The effect of $\mathrm{pH}$ on decolorization of Reactive Violet 5 by Paracoccus sp. GSM2 was determined over a wide range of $\mathrm{pH} 4.0$ to 10.0 with an interval of $\mathrm{pH}$ 1. The isolate showed the maximum of $100 \%$ decolorization at $\mathrm{pH} 7.0$ at $30^{\circ} \mathrm{C}$. Following the increases from either side of neutral $\mathrm{pH}$, the percentage of decolorization decreased steadily from $97 \%$ to $40 \%$ on the alkaline side while steep decline in percent decolorization from $89 \%$ to less than $15 \%$ on acidic side was found. More than $88 \%$ of decolorization was observed in a wide range of pH 6.0 to 8.0 (Figure 4). Similar optimum $\mathrm{pH}$ was observed in the decolorization of the same dye Reactive Violet 5 by bacterial consortium SB4 [14]. Chan and Kuo [32] reported that the neutral $\mathrm{pH}$ would be more favorable for decolorization of the azo dyes and is suitable for industrial applications.

3.4. Effect of Temperature. Similarly in the temperature optimization study, the dye decolorization activity of Paracoccus sp. GSM2 was found to increase with increase in incubation temperature from 20 to $30^{\circ} \mathrm{C}$. Further increase in temperature, decolorization was decreased by $23 \%$ and $44 \%$ at $40^{\circ} \mathrm{C}$ and $45^{\circ} \mathrm{C}$, respectively, and almost no activity was found at $50^{\circ} \mathrm{C}$ (Figure 5). This might be attributed to the adverse effect of high temperature on enzyme activities [33]. Tamboli et al. [16] also found the decrease in dye decolorization efficiency of Sphingobacterium sp. ATM for color removal beyond $30^{\circ} \mathrm{C}$, which may be due to the thermal inactivation of the decolorizing enzymes.

3.5. Effect of Initial Dye Concentration. The decolorization performance of Reactive Violet 5 by the Paracoccus sp. GSM2 was studied by increasing initial dye concentration (100$800 \mathrm{mg} / \mathrm{L}$ ). We observed that the percentage of decolorization

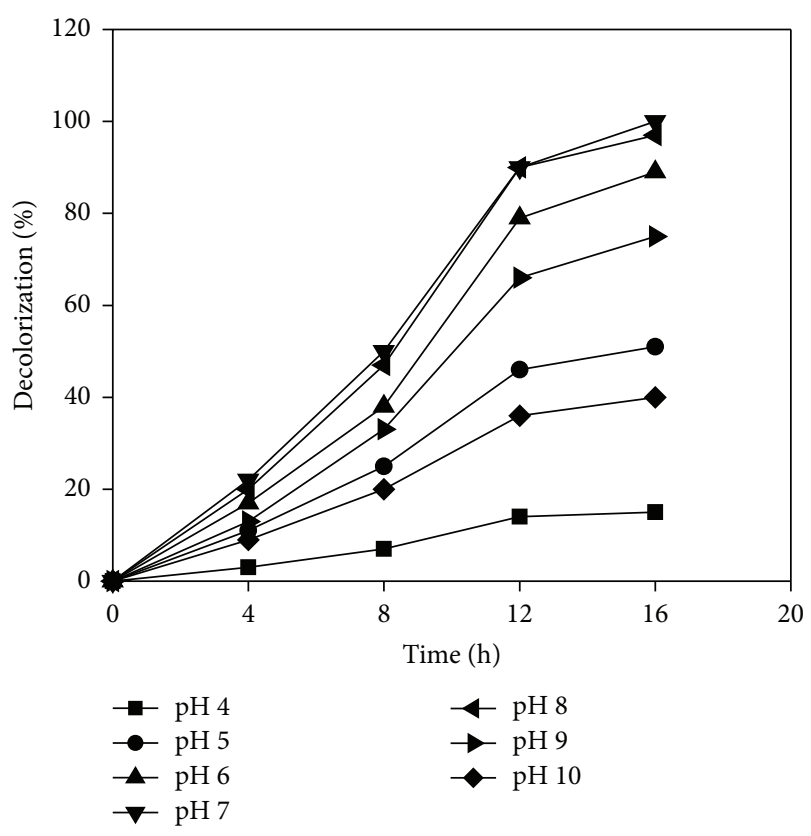

Figure 4: Effect of $\mathrm{pH}$ on decolorization of Reactive Violet 5.

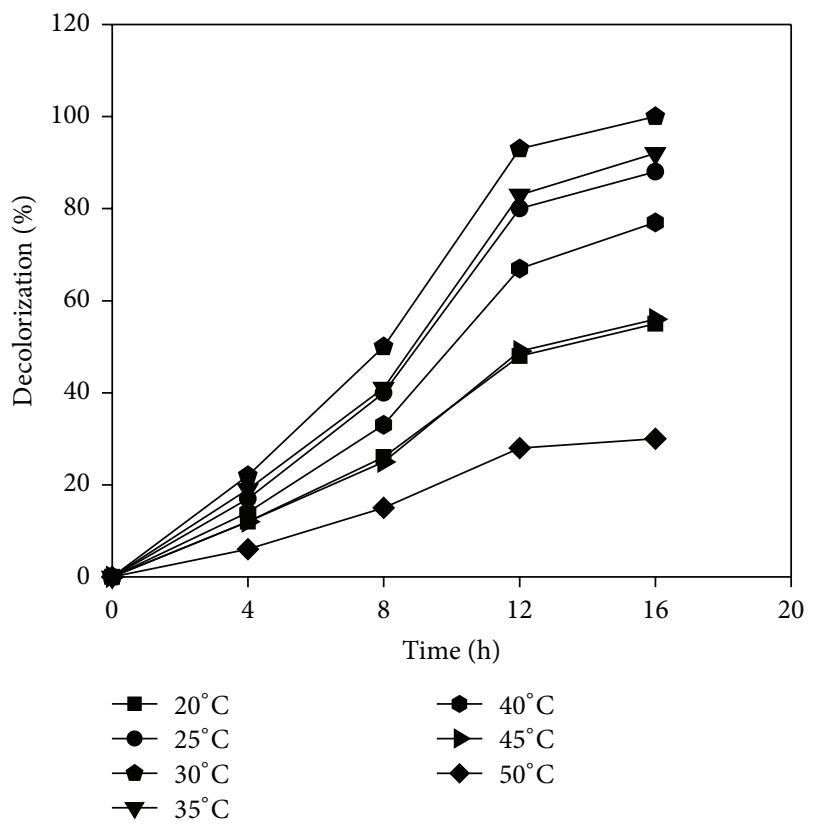

FIGURE 5: Effect of temperature on decolorization of Reactive Violet 5.

was decreased slowly with increasing dye concentration (Figure 6). It could effectively decolorize up to $100 \mathrm{mg} / \mathrm{L}$ of Reactive Violet 5 (100\%) within $16 \mathrm{~h}$ and is decreased to 63\%, when dye concentration increased to $800 \mathrm{mg} / \mathrm{L}$ and decolorization time increases from $16 \mathrm{~h}$ to $38 \mathrm{~h}$, respectively. Lower percentage of decolorization and enhanced time period at high dye concentration may be attributed to the presence of four sulfonic acid groups on Reactive Violet 5 which acts as 


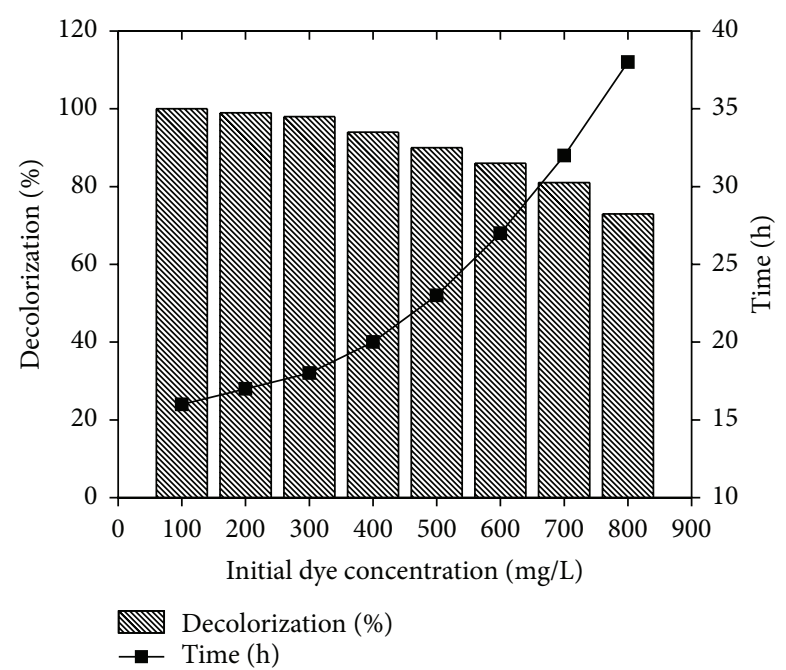

FIgURE 6: Effect of initial dye concentration on decolorization of Reactive Violet 5.

detergent exerting inhibitory effect on growth of Paracoccus sp. GSM2 [14].

3.6. Effect of Salt Concentration. Textile industry effluents generally contain chloride salts of sodium and potassium which are most widely used for salting out of dyes and discharged along with unused dyes. Hence, the present investigation was undertaken to study the effect of salt concentration (1-6\% w/v) on decolorization of Reactive Violet 5 by the strain GSM2. The organism showed satisfactory decolorization up to maximum of $2 \%$ salt concentration in MSM under optimum conditions after $16 \mathrm{~h}$ of incubation (Figure 7). Previously De Baere et al. [34] have stated that sodium concentration higher than $3 \mathrm{~g} / \mathrm{L}$ can cause inhibition of most of the bacterial metabolism. But, contrary to the above statement, we could notice $74 \%$ and $45 \%$ of decolorization at $3 \%$ and $4 \%$ of salt concentration, respectively. Which agree with the earlier report [14]. Negligible activity was observed when $6 \%$ of salt concentration was employed into the medium. This may be attributed to the inhibition of bacteria at high salt concentration due to plasmolysis or loss of activity of cells [35].

3.7. Effect of Different Concentrations of Yeast Extract. Paracoccus sp. GSM2 was able to degrade Reactive Violet 5 $(100 \mathrm{mg} / \mathrm{L})$ efficiently in the presence of yeast extract as a cosubstrate. Among all other nitrogen sources, only yeast extract that served as better nitrogen source for decolorization of Reactive Violet 5 within less time was selected for further experiments (data not shown). Effect of different concentrations of yeast extract $(0.1-2.0 \mathrm{~g} / \mathrm{L})$ in MSM on the decolorization efficacy of GSM2 was evaluated (Figure 8). Addition of $1 \mathrm{~g} / \mathrm{L}$ of yeast extract enhanced the decolorization activity and complete decolorization of Reactive Violet 5 was recorded within $16 \mathrm{~h}$. Further increase in yeast extract concentration has no effect on decolorization activity. Thus,

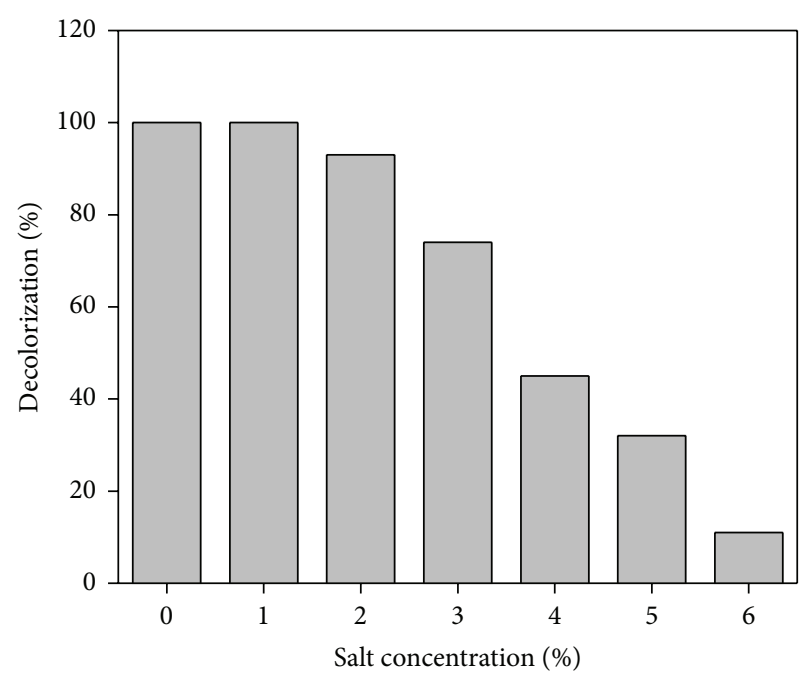

FIGURE 7: Effect of salt concentration on decolorization of Reactive Violet 5 .

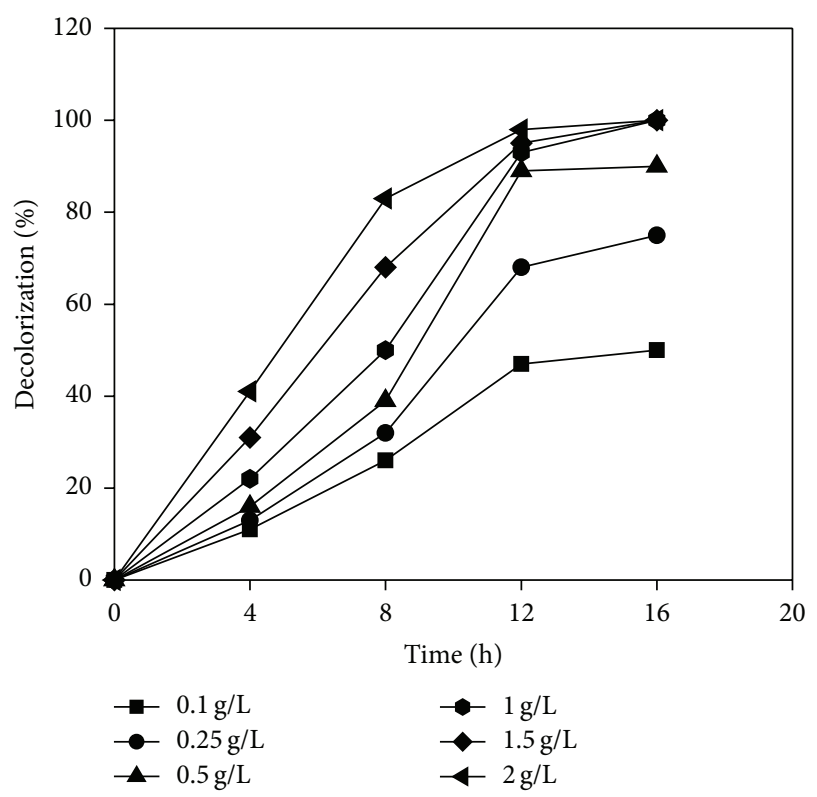

FIGURE 8: Effect of yeast extract concentration on decolorization of Reactive Violet 5.

to make the process economical $1 \mathrm{~g} / \mathrm{L}$ of yeast extract concentration was found to be optimum. Similar results were reported by Jain et al. [14] where their findings proposed that yeast extract was essential for regeneration of NADH which acts as an electron donor in azo bond reduction.

3.8. Decolorization of Structurally Different Azo Dyes. Structurally different azo dyes were most widely used in textile processing industries, and, therefore, the effluents from the industry are markedly diverse in composition [36]. Thus, Paracoccus sp. GSM2 was tested for its ability to decolorize five other structurally different azo dyes such as Reactive Red 2, Reactive Orange 16, Reactive Black 5, Reactive Blue 4, and 
TABle 2: Decolorization of structurally different azo dyes by Paracoccus sp. GSM2.

\begin{tabular}{lccc}
\hline Reactive dyes & $\lambda_{\max }(\mathrm{nm})$ & \% Decolorization & Time (hours) \\
\hline Reactive Red 2 & 538 & 100 & 12 \\
Reactive Orange 16 & 416 & 99 & 18 \\
Reactive Blue 4 & 595 & 92 & 22 \\
Reactive Black 5 & 597 & 82 & 30 \\
Reactive Green 19A & 540 & 73 & 38 \\
\hline
\end{tabular}

Reactive Green $19 \mathrm{~A}$. The organism effectively decolorized all structurally different azo dyes within $38 \mathrm{~h}$ (Table 2). The efficiency was $100 \%$ for Reactive Red 2, followed by $99 \%$ for Reactive Orange 16, 92\% for Reactive Blue 4, 82\% for Reactive Black 5, and 73\% for Reactive Green $19 \mathrm{~A}$. We presume that decolorization of structurally different azo dyes by Paracoccus sp. GSM2 within $38 \mathrm{~h}$ might be the first. This variation in the decolorization of different dyes might be attributed to the structural differences, high molecular weight, and presence of inhibitory groups like $-\mathrm{NO}_{2}$ and $-\mathrm{SO}_{3} \mathrm{Na}$ in the dyes [36]. The present study confirms the ability of strain GSM2 to decolorize different azo dyes with decolorization efficiency of more than $70 \%$. Thus, the strain GSM2 could be successfully employed for the treatment of textile industry effluents containing various azo dyes.

3.9. Decolorization and Biodegradation Studies. To disclose the possible mechanism of dye decolorization, we also analyzed the degraded products of Reactive Violet 5 by UV-Vis and FT-IR techniques. UV-Vis absorbance of $200-800 \mathrm{~nm}$ of Reactive Violet 5 in MSM showed single peak in visible region at $558 \mathrm{~nm}\left(\lambda_{\max }\right)$ and two intense peaks in UV region near 250 and $325 \mathrm{~nm}$, respectively, correspond to phenyl and naphthyl rings of Reactive Violet 5 (Figure 9) [37]. During decolorization azo bond in Reactive Violet 5 was broken down and peak at $558 \mathrm{~nm}$ continuously decreased and completely disappeared within $16 \mathrm{~h}$, without any shift in $\lambda_{\max }$. Similar observations have been recorded by Jain et al. [14]. According to Asad et al. [12] decolorization of dyes by bacteria could be due to adsorption by microbial cells or to biodegradation. In the case of adsorption, the UVVis absorption peaks decrease approximately in proportion to each other, whereas, in biodegradation, either the major visible light absorbance peak disappears completely or a new peak appears. The observation of cell mass showed that Paracoccus sp. GSM2 retained their natural color after decolorization of Reactive Violet 5. FT-IR spectrum of control dye with metabolites extracted after complete decolorization $(16 \mathrm{~h})$ clearly indicated the biodegradation of the parent dye compound by Paracoccus sp. GSM2 (Figure 10). FTIR analysis of control and decolorized samples showed significant differences in specific peaks of Reactive Violet 5 fingerprint region $\left(550-4000 \mathrm{~cm}^{-1}\right)$. FT-IR spectra of control Reactive Violet 5 show specific peaks for multisubstituted benzene ring, where peaks at 1140.83,1338.36, 1186.18, and $1549.25 \mathrm{~cm}^{-1}$ corresponded to two $\mathrm{SO}_{3} \mathrm{H}$ groups, symmetric $\mathrm{SO}_{2}$, and $-\mathrm{N}=\mathrm{N}-$ (azo bond), whereas parasubstituted azo

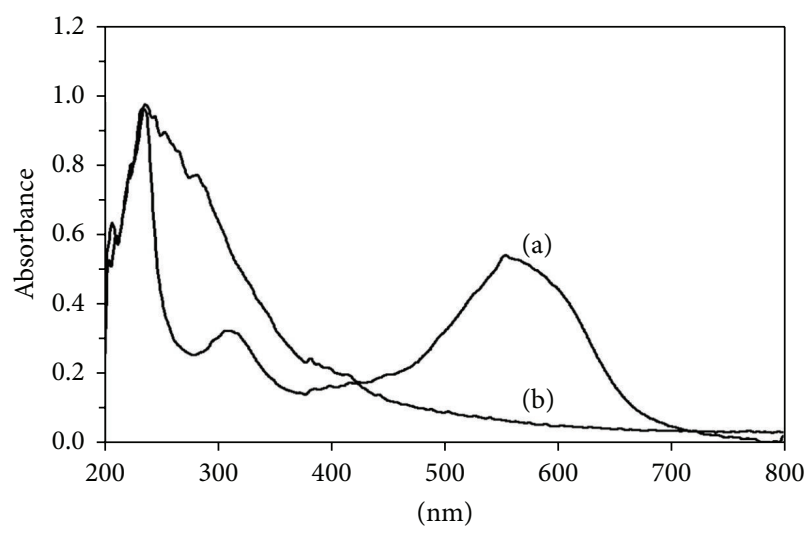

Figure 9: UV-Vis spectra of Reactive Violet 5 before and after decolorization by Paracoccus sp. GSM2 (a, 0 hour; b, 16 hours).

benzene showed bands near $1433.48 \mathrm{~cm}^{-1}$. Reactive Violet 5 is a metal containing textile azo dye where carbonic ion is bonded with a central copper metal ion giving rise to asymmetrical stretching which was observed near $1614.85 \mathrm{~cm}^{-1}$ [38]. Peak at $1650.89 \mathrm{~cm}^{-1}$ represents the primary amide of the parent structure of Reactive Violet 5. The FT-IR spectra of $16 \mathrm{~h}$ extracted metabolites of degraded Reactive Violet 5 showed peaks at 1651.91 and $3252.48 \mathrm{~cm}^{-1}$ which indicates the production of primary amine and secondary amide, respectively, during biodegradation of Reactive Violet 5. Absence of peaks at $671,721,763$, and $817 \mathrm{~cm}^{-1}$ indicates the breakdown of benzene ring or the loss of aromatic nature of the compound. Jain et al. [14] reported similar kind of benzene ring fission in the same dye Reactive Violet 5 by bacterial consortium SB4. Correspondingly, breakdown of azo bond was confirmed by the absence of spectral peak at $1549.25 \mathrm{~cm}^{-1}$, while the absence of the peaks around 1300 and $1165-1150 \mathrm{~cm}^{-1}$ clearly indicates the degradation of $\mathrm{S}=\mathrm{O}$ bonds. Peaks at 2927.40 and $2960.03 \mathrm{~cm}^{-1}$ in control Reactive Violet 5 and degraded metabolites, respectively, show the asymmetrical stretching of $\mathrm{C}-\mathrm{H}$ in $\mathrm{CH}_{3}$. Similar kind of asymmetrical stretching of peak at $2856 \mathrm{~cm}^{-1}$ in control Reactive Violet 5 shows that the asymmetrical stretching for $\mathrm{C}-\mathrm{H}$ stretching was observed in degradation of the same dye Reactive Violet 5 [39]. On the basis of above results, it can be concluded that Paracoccus sp. GSM2 has ability to mineralize Reactive Violet 5 completely.

\section{Conclusion}

The present study showed that a bacterial strain Paracoccus sp. GSM2 is capable of degrading Reactive Violet 5 as a sole source of carbon with minimal nutritional requirements under static condition. The potential of this strain has ability to decolorize Reactive Violet 5 in a wide range of $\mathrm{pH}$, temperature, salt, and initial dye concentrations, which is significant for its commercial application. The FT-IR results showed complete loss of the aromatic nature of the dye Reactive Violet 5 by Paracoccus sp. GSM2. Furthermore, strain GSM2 had the ability to decolorize five other structurally different 


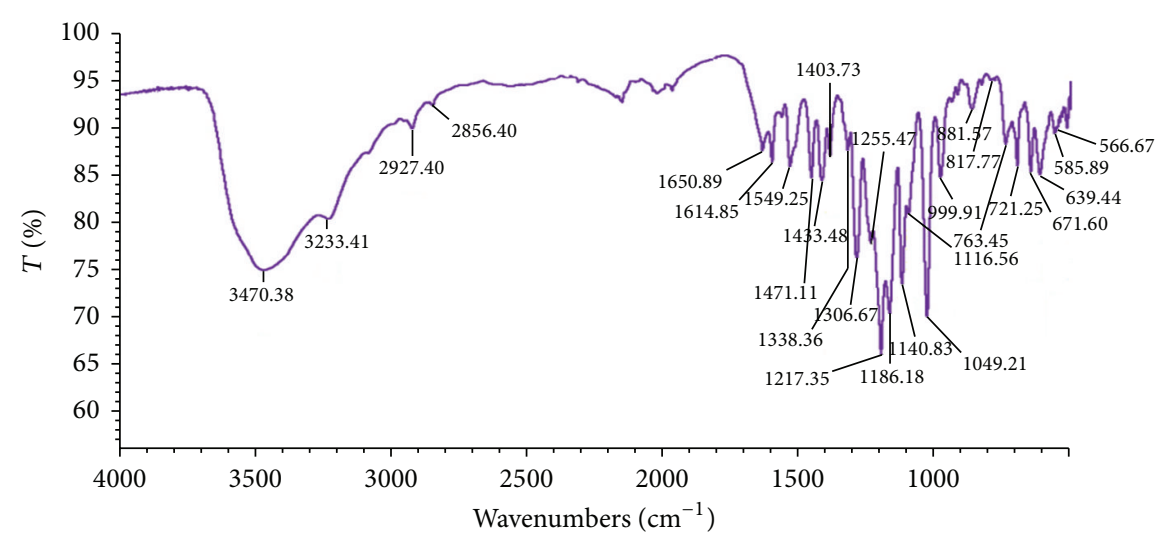

(a)

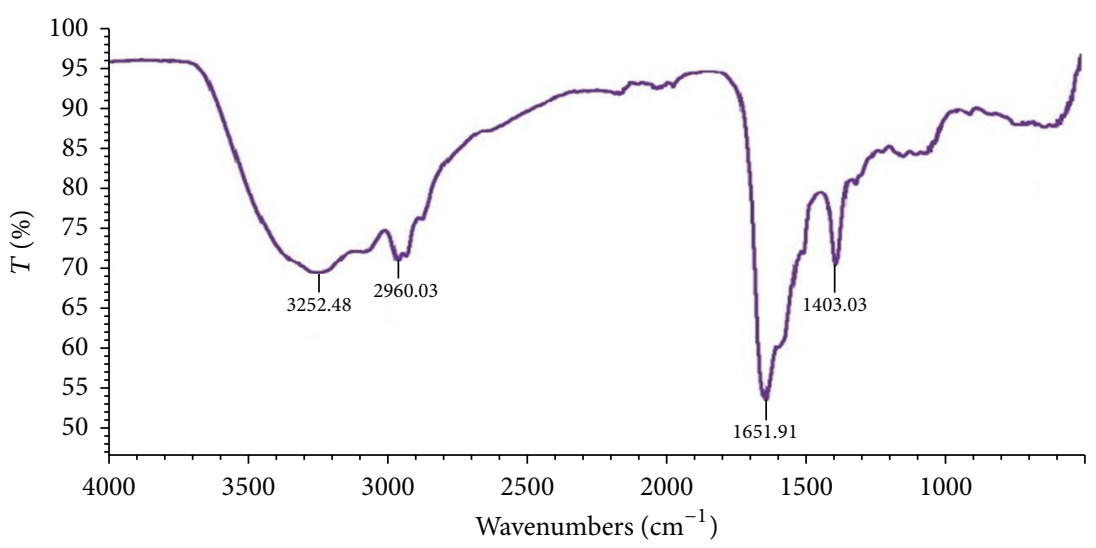

(b)

FIGURE 10: FT-IR spectra of (a) control Reactive Violet 5 and (b) its degradation metabolites.

azo dyes indicating its field applicability in the treatment of textile effluents. Therefore, Paracoccus sp. GSM2 is the highly promising bacterium that can be used for the treatment of textile industry effluents containing various reactive azo dyes.

\section{Conflict of Interests}

The authors declare that there is no conflict of interests regarding the publication of this paper.

\section{Acknowledgment}

The authors are thankful to Professor A. Venkataraman, Chairman, Department of Materials Science, Gulbarga University, Gulbarga, for providing FT-IR facility. Authors are also thankful to Gulbarga University, Gulbarga for providing research student fellowship during the research work.

\section{References}

[1] H. Zollinger, Color Chemistry-Synthesis, Properties and Application of Organic Dyes and Pigments, VCH Publishers, New York, NY, USA, 1987.

[2] V. K. Gupta, R. Jain, A. Nayak, S. Agarwal, and M. Shrivastava, "Removal of the hazardous dye-Tartrazine by photodegradation on titanium dioxide surface," Materials Science and Engineering C, vol. 31, no. 5, pp. 1062-1067, 2011.

[3] J.-S. Chang, C. Chou, Y.-C. Lin, P.-J. Lin, J.-Y. Ho, and T. Lee Hu, "Kinetic characteristics of bacterial azo-dye decolorization by Pseudomonas luteola," Water Research, vol. 35, no. 12, pp. 28412850, 2001.

[4] C. O’Neill, F. R. Hawkes, D. L. Hawkes, N. D. Lourenco, H. M. Pinheiro, and W. Delee, "Color in textile effluents sources, measurement, discharge consents and simulation: a review," Journal of Chemical Technology and Biotechnology, vol. 74, no. 11, pp. 1009-1018, 1999.

[5] S. Sandhya, S. Padmavathy, K. Swaminathan, Y. V. Subrahmanyam, and S. N. Kaul, "Microaerophilic-aerobic sequential batch reactor for treatment of azo dyes containing simulated wastewater," Process Biochemistry, vol. 40, no. 2, pp. 885-890, 2005.

[6] P. C. Vandevivere, R. Bianchi, and W. Verstraete, "Treatment and reuse of wastewater from the textile wet-processing Industry: review of emerging technologies," Journal of Chemical Technology and Biotechnology, vol. 72, pp. 289-302, 1998.

[7] P. Verma and D. Madamwar, "Decolourization of synthetic dyes by a newly isolated strain of Serratia marcescens," World Journal of Microbiology and Biotechnology, vol. 19, no. 6, pp. 615-618, 2003.

[8] R. G. Saratale, G. D. Saratale, D. C. Kalyani, J. S. Chang, and S. P. Govindwar, "Enhanced decolorization and biodegradation 
of textile azo dye Scarlet $\mathrm{R}$ by using developed microbial consortium-GR," Bioresource Technology, vol. 100, no. 9, pp. 2493-2500, 2009.

[9] Z. W. Myslak and H. M. Bolt, "Occupational exposure to azo dyes and risk of bladder cancer," ZblArbeitsmed, vol. 38, pp. 310$321,1988$.

[10] H. Wang, X.-W. Zheng, J.-Q. Su, Y. Tian, X.-J. Xiong, and T.-L. Zheng, "Biological decolorization of the reactive dyes Reactive Black 5 by a novel isolated bacterial strain Enterobacter sp. EC3," Journal of Hazardous Materials, vol. 171, no. 1-3, pp. 654-659, 2009.

[11] P. Kaushik and A. Malik, "Fungal dye decolourization: recent advances and future potential," Environment International, vol. 35, no. 1, pp. 127-141, 2009.

[12] S. Asad, M. A. Amoozegar, A. A. Pourbabaee, M. N. Sarbolouki, and S. M. M. Dastgheib, "Decolorization of textile azo dyes by newly isolated halophilic and halotolerant bacteria," Bioresource Technology, vol. 98, no. 11, pp. 2082-2088, 2007.

[13] S. Moosvi, X. Kher, and D. Madamwar, "Isolation, characterization and decolorization of textile dyes by a mixed bacterial consortium JW-2," Dyes and Pigments, vol. 74, no. 3, pp. 723729, 2007.

[14] K. Jain, V. Shah, D. Chapla, and D. Madamwar, "Decolorization and degradation of azo dye-reactive Violet 5R by an acclimatized indigenous bacterial mixed cultures-SB4 isolated from anthropogenic dye contaminated soil," Journal of Hazardous Materials, vol. 213-214, pp. 378-386, 2012.

[15] D. C. Kalyani, A. A. Telke, R. S. Dhanve, and J. P. Jadhav, "Ecofriendly biodegradation and detoxification of Reactive Red 2 textile dye by newly isolated Pseudomonas sp. SUK1," Journal of Hazardous Materials, vol. 163, no. 2-3, pp. 735-742, 2009.

[16] D. P. Tamboli, M. B. Kurade, T. R. Waghmode, S. M. Joshi, and S. P. Govindwar, "Exploring the ability of Sphingobacterium sp. ATM to degrade textile dye Direct Blue GLL, mixture of dyes and textile effluent and production of polyhydroxyhexadecanoic acid using waste biomass generated after dye degradation," Journal of Hazardous Materials, vol. 182, no. 1-3, pp. 169-176, 2010.

[17] J. Cheriaa, M. Khaireddine, M. Rouabhia, and A. Bakhrouf, "Removal of triphenylmethane dyes by bacterial consortium," The Scientific World Journal, vol. 2012, Article ID 512454, 9 pages, 2012.

[18] C. Brilon, W. Beckmann, M. Hellwig, and H.-J. Knackmuss, "Enrichment and isolation of naphthalenesulfonic acidutilizing pseudomonads," Applied and Environmental Microbiology, vol. 42, no. 1, pp. 39-43, 1981.

[19] J. G. Holt, N. R. Krieg, P. H. A. Sneath, J. T. Staley, and S. T. Williams, Bergey's Manual of Determinative Bacteriology, Williams \& Wilkins, Baltimore, Md, USA, 9th edition, 1994.

[20] N. Saitou and M. Nei, "The neighbor-joining method: a new method for reconstructing phylogenetic trees," Molecular Biology and Evolution, vol. 4, no. 4, pp. 406-425, 1987.

[21] J. Felsenstein, "Confidence limits on phylogenies: an approach using the bootstrap," Evolution, vol. 39, pp. 783-791, 1985.

[22] N. Takezaki, A. Rzhetsky, and M. Nei, "Phylogenetic test of the molecular clock and linearized trees," Molecular Biology and Evolution, vol. 12, no. 5, pp. 823-833, 1995.

[23] K. Tamura, M. Nei, and S. Kumar, "Prospects for inferring very large phylogenies by using the neighbor-joining method," Proceedings of the National Academy of Sciences of the United States of America, vol. 101, no. 30, pp. 11030-11035, 2004.
[24] K. Tamura, D. Peterson, N. Peterson, G. Stecher, M. Nei, and S. Kumar, "MEGA5: molecular evolutionary genetics analysis using maximum likelihood, evolutionary distance, and maximum parsimony methods," Molecular Biology and Evolution, vol. 28, no. 10, pp. 2731-2739, 2011.

[25] A. Khalid, M. Arshad, and D. E. Crowley, "Accelerated decolorization of structurally different azo dyes by newly isolated bacterial strains," Applied Microbiology and Biotechnology, vol. 78, no. 2, pp. 361-369, 2008.

[26] S. R. Dave and R. H. Dave, "Isolation and characterization of Bacillus thuringiensis for Acid red 119 dye decolourisation," Bioresource Technology, vol. 100, no. 1, pp. 249-253, 2009.

[27] X. Peng, J. S. Zhang, Y. Y. Li, W. Li, G. M. Xu, and Y. C. Yan, "Biodegradation of insecticide carbofuran by Paracoccus sp. YM3," Journal of Environmental Science and Health-B: Pesticides, Food Contaminants, and Agricultural Wastes, vol. 43, no. 7, pp. 588-594, 2008.

[28] Y. Bai, Q. Sun, C. Zhao, D. Wen, and X. Tang, "Microbial degradation and metabolic pathway of pyridine by a Paracoccus sp. strain BW001," Biodegradation, vol. 19, no. 6, pp. 915-926, 2008.

[29] H. Zhang, A. Kallimanis, A. I. Koukkou, and C. Drainas, "Isolation and characterization of novel bacteria degrading polycyclic aromatic hydrocarbons from polluted Greek soils," Applied Microbiology and Biotechnology, vol. 65, no. 1, pp. 124131,2004

[30] T. L. Hu, "Decolourization of reactive azo dyes by transformation with Pseudomonas luteola," Bioresource Technology, vol. 49, no. 1, pp. 47-51, 1994.

[31] C. I. Pearce, J. R. Lloyd, and J. T. Guthrie, "The removal of colour from textile wastewater using whole bacterial cells: a review," Dyes and Pigments, vol. 58, no. 3, pp. 179-196, 2003.

[32] J. Chan and T. Kuo, "Kinetics of bacterial decolorization of azo dye with Escherichia coli $\mathrm{NO}_{3}$," Bioresource Technology, vol. 75, no. 2, pp. 107-111, 2000.

[33] D. Cetin and G. Donmez, "Decolorization of reactive dyes by mixed cultures isolated from textile effluent under anaerobic condition," Enzyme and Microbial Technology, vol. 38, pp. 926930, 2006.

[34] L. A. De Baere, M. Devocht, P. Van Assche, and W. Verstraete, "Influence of high $\mathrm{NaCl}$ and $\mathrm{NH}_{4} \mathrm{Cl}$ salt levels on methanogenic associations," Water Research, vol. 18, no. 5, pp. 543-548, 1984.

[35] T. Panswad and C. Anan, "Specific oxygen, ammonia, and nitrate uptake rates of a biological nutrient removal process treating elevated salinity wastewater," Bioresource Technology, vol. 70, no. 3, pp. 237-243, 1999.

[36] P. S. Patil, U. U. Shedbalkar, D. C. Kalyani, and J. P. Jadhav, "Biodegradation of Reactive Blue 59 by isolated bacterial consortium PMB11," Journal of Industrial Microbiology and Biotechnology, vol. 35, no. 10, pp. 1181-1190, 2008.

[37] F. He, W. Hu, and Y. Li, "Biodegradation mechanisms and kinetics of azo dye $4 \mathrm{BS}$ by a microbial consortium," Chemosphere, vol. 57, no. 4, pp. 293-301, 2004.

[38] R. Silverstein and F. Webster, Spectrometric Identification of Organic Compounds, Wiley, New York, NY, USA, 1998.

[39] C. Desai, K. Jain, B. Patel, and D. Madamwar, "Efficacy of bacterial consortium-AIE2 for contemporaneous $\mathrm{Cr}(\mathrm{VI})$ and azo dye bioremediation in batch and continuous bioreactor systems, monitoring steady-state bacterial dynamics using qPCR assays," Biodegradation, vol. 20, no. 6, pp. 813-826, 2009. 

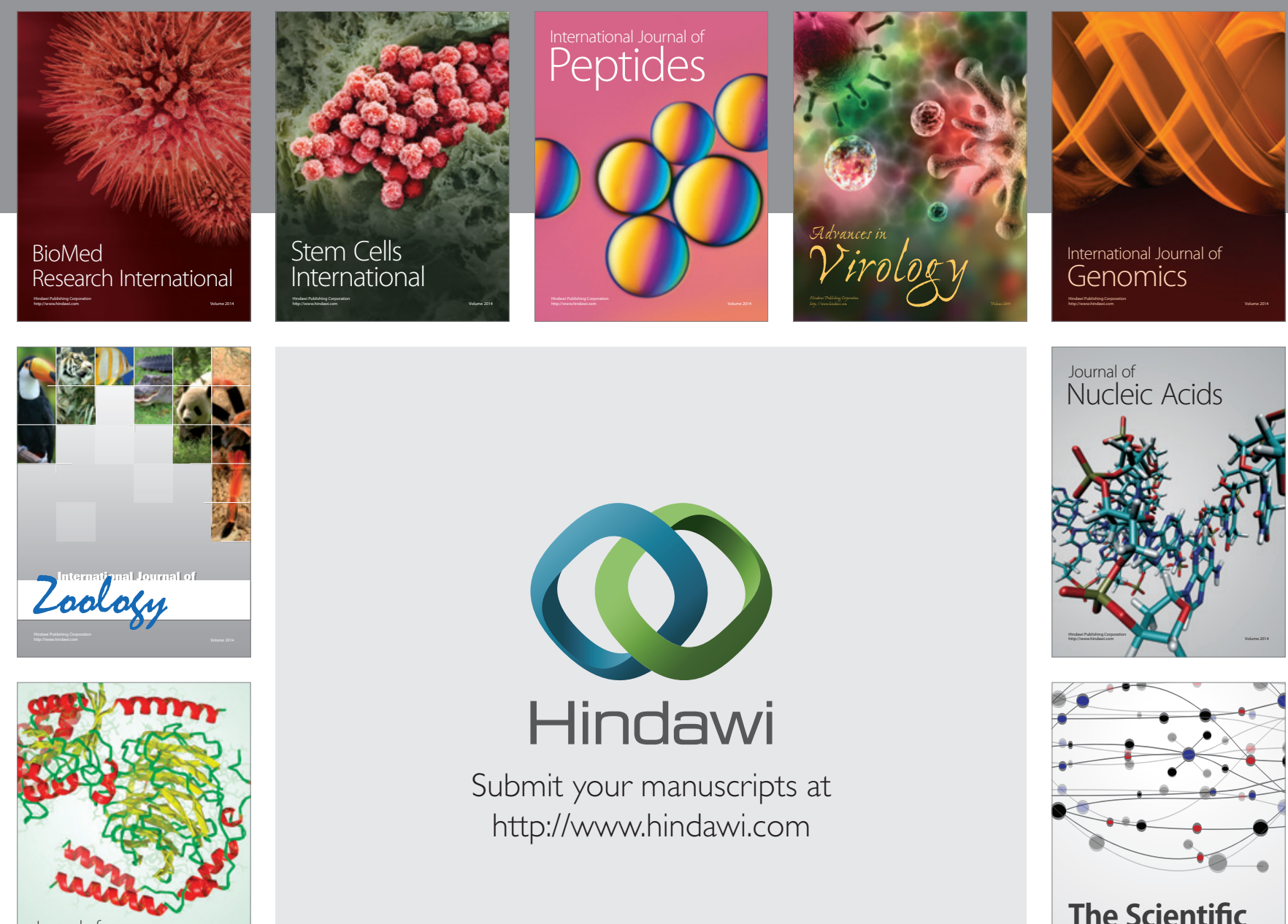

Submit your manuscripts at

http://www.hindawi.com

Journal of
Signal Transduction
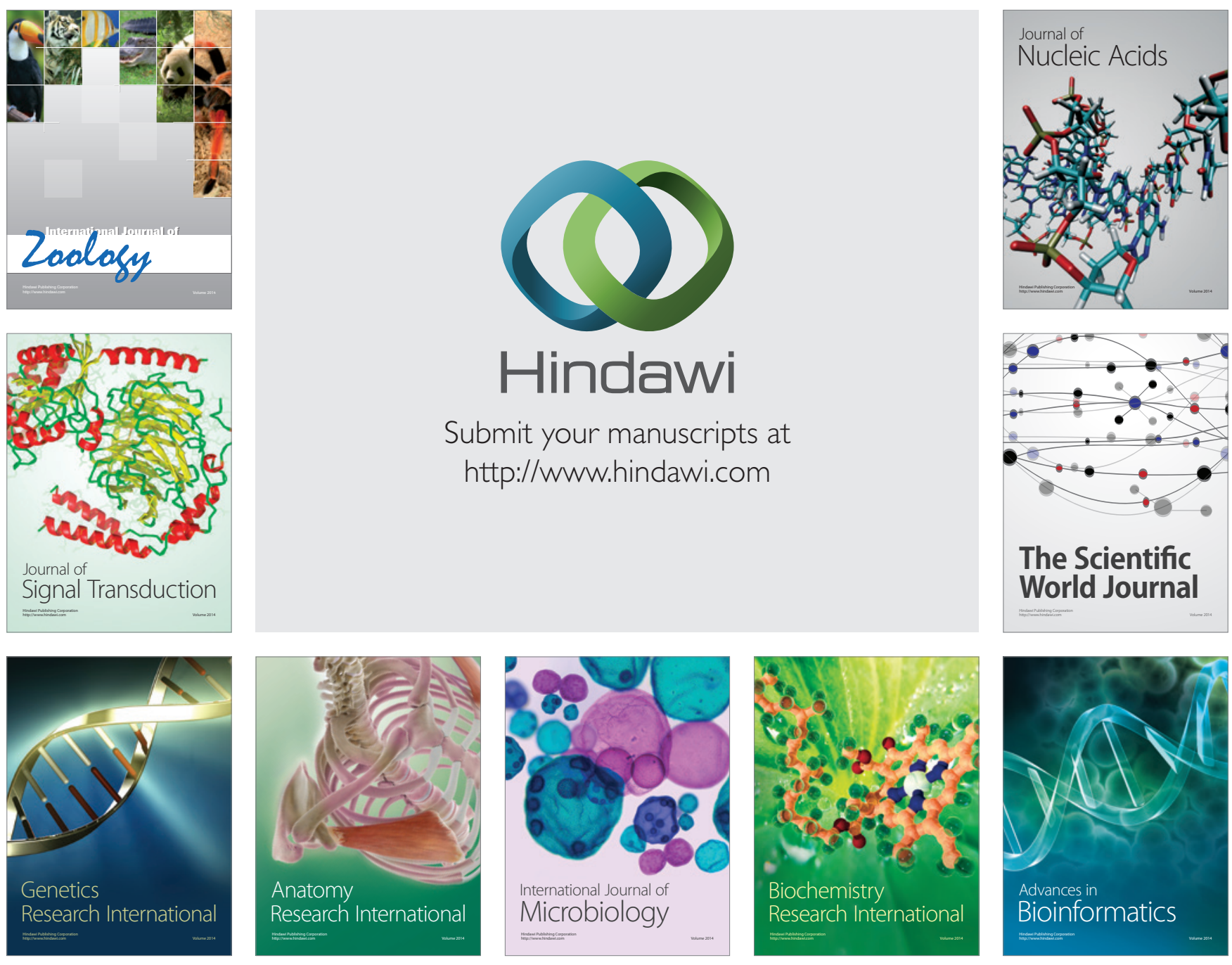

The Scientific World Journal
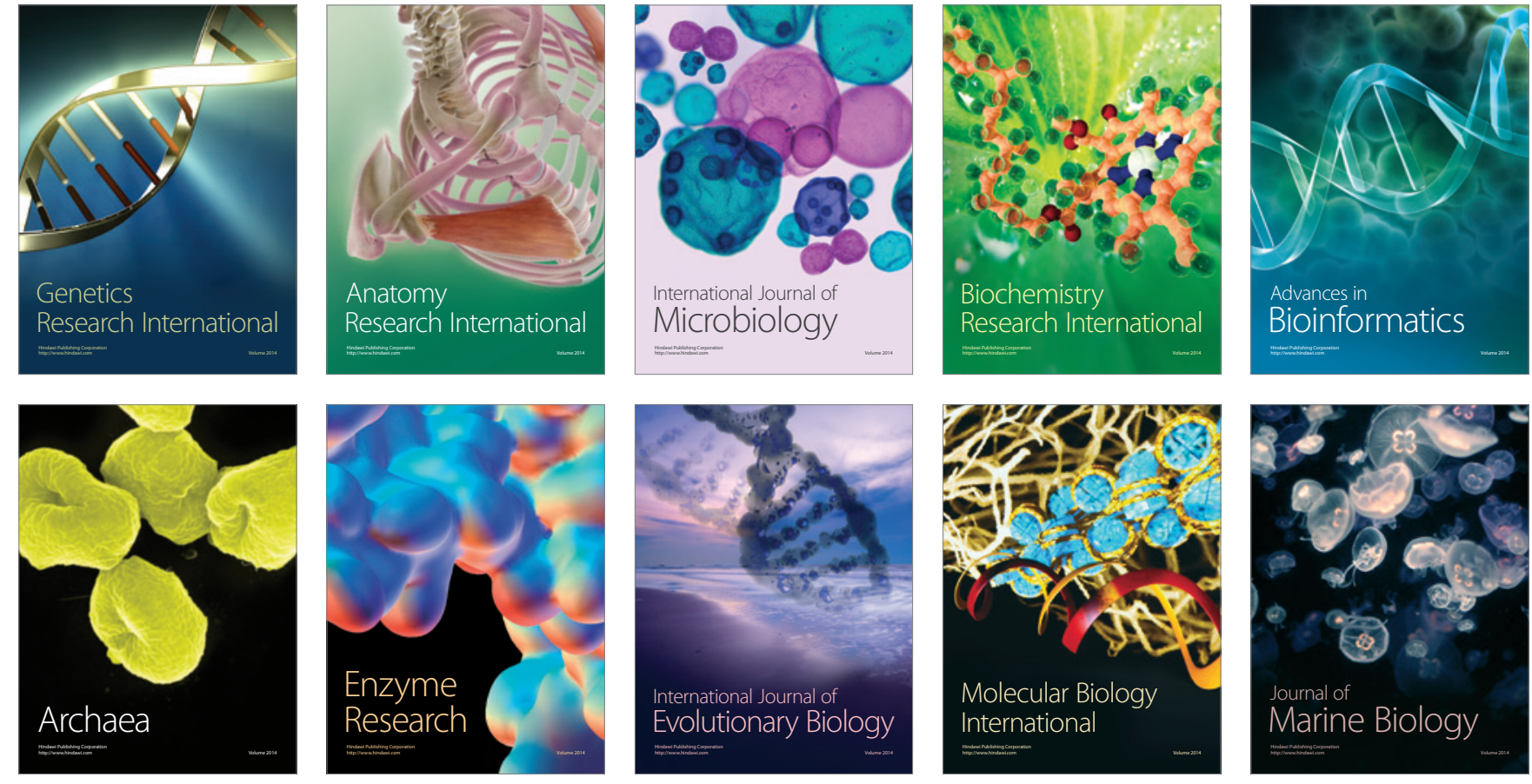